\title{
Biodiversity Conservation through Peoples Protected Areas (PPA)
}

\author{
Garima Tiwari
}

\begin{abstract}
The health and vitality of the forest ecosystem is needed to evolves package of peoples friendly minimal damage forest management practice which could contribute to avoid the destruction of the forest and enhance the well being of the people. As part of strategy to translate above philosophy into implementable action programme Chhattisgarh state of India is the first state in the country to have enunciated Peoples oriented state forest policy which provides new direction to forest management. Chhattisgarh as 'Herbal state'- has initiated efforts on conservation, development, non destructive harvesting, processing and marketing of herbal medicine in the forest of the state. The paper presents a case study of steps after implementation of this management programme. The study was conducted on three sample villages of Chhattisgarh state. PRA, RRA methods were used for primary data collection. After the analysis study concluded that the villagers are not able to get true value of the forest produce because of inadequate marketing facilities available to them. Thus proper development of marketing infrastructure is must. Improvement of the economic conditions of forest dwellers will reduce villagers dependency over forest which will be beneficial for protection of biodiversity of forest.
\end{abstract}

Index Terms-Joint forest management, peoples protected area, herbal state, non wood forest produce.

\section{INTRODUCTION}

The 50 years of independence have witnessed profound changes in demographic, economic and social make up of the country. Environment and percentage of forest cover also dwindle by the time. Forest management during last 50 years of independence has made a full circle: From conversion to conservation [1]. But the most important changes that have affected Forest management during last 60 years are as India become a democratic nation, the demand on forest has at least trebled, environmental awareness of people increased .The changes particularly during last 20 years or so had epoch making impact on forest management.

India richly deserves the credit for having been one of the earliest among developing countries to initiate scientific Forest Management about a century half ago. The appointment of Sir Dietrich Brandies as the first Inspector General of forest in 1864 is seen as the beginning of the scientific forestry in India though forestry activities had begun in some province in the early part of nineteenth century [2].

In developing countries poverty map broadly tallies with

Manuscript received May 11, 2014; revised July 3, 2014

Garima Tiwari is with Department of Forestry, Wildlife and Environmental Sciences, Guru Ghasidas Vishwavidhyalya, Bilaspur, (C.G.) India (e-mail: aalaptiwari@gmail.com). forest and forest are fulfilling the requirement of the broad range of the goods and services for society. For maintaining the health and vitality of the forest ecosystem what is needed is to evolve package of peoples friendly minimal damage forest management practice which could contribute to avoid the destruction of the forest and enhance the well being of the people.

As part of strategy to translate above philosophy into implementable action programme Joint Forest Management (JFM) is a collaborative management regime, initiated by the Ministry of Environment of Forests, Government of India in the 1990s building a partnership with the local communities for rehabilitation of the degraded forests, with emphasis on protection, management and development of the forest resources by the tribal communities and the women, following guidelines of the National Forest Policy in 1988 [2]. As per forest policy of 1988 foundation of participatory forest management come forward after then in forestry sector importance was given to people's participation.

The present system of forest management favors people's contribution, fencing approach, empowerment of the people, sharing of product and responsibilities. The concept of and philosophy is well matured where its systematic development and replication is in its revolutionary phase [3].

Thus, there was a paradigm shift from centralized, controlled and custodial forest management to democratic, devolving, participatory community-based natural resource management, resulting in orientation from revenue generation to resource development, single benefit to multiple benefits, mono-culture to multiple cropping and above all unilateral decision making to participatory process.

All the states of India have made Joint Forest Management a hall mark of their forest policy and are expanding the area under JFM through eternally aided projects. But the long term viability of JFM appears doubtful unless the issues of the poverty alleviation, has initiated efforts on conservation, development empowerment, sustainable development and forest regeneration are dealt together.

Sustainability is the key issue in the present-day forest Management in India. The decentralized management regime covers bio-diversity, participation, locale, livelihoods, practices, stakeholder, devolution, empowerment, governance, development and so on [3].

Adoption of Sustainable Livelihood approach amply takes care of these issues to maintain of enhance natural resources productivity, secure ownership of and access to assets and income earning activities as well as to ensure adequate stock and flows of food and cash to meet basic needs.

Sustainable livelihood approach aims to promote a holistic vision of development that includes income generating 
activities, natural resource management, people's empowerment, use of appropriate technology, financial services and good governance [4].

Chhattisgarh is one of the youngest States of the Indian nation, formerly a part of Madhya Pradesh was formed on November 1, 2000 as the 26th state of the Indian Union. The geographical area of the State covers over 135,000 square kilometer, which covers $4.4 \%$ of the total geographical area of the country. Over 0.59 lakh sq. $\mathrm{km}$ area in the state is under forest constituting about $44 \%$ of its geographical area (Fig. 1). Out of total 19720 villages in the State, there are 11,185 villages located within $5 \mathrm{kms}$ periphery of forests [5].

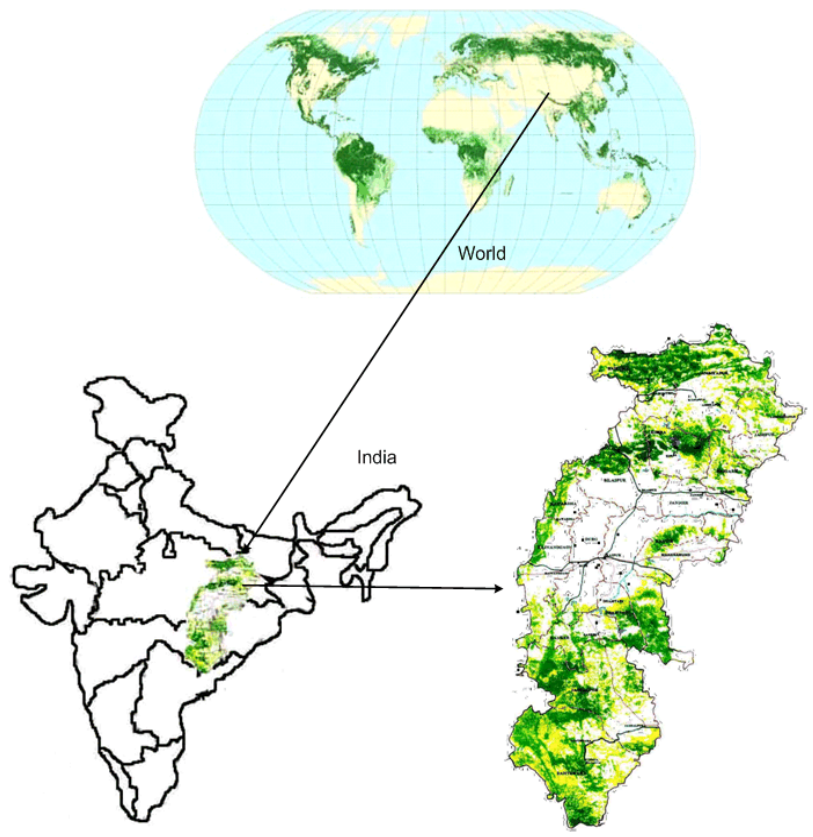

Fig. 1. Forest map of Chhattisgarh State of India.

Chhattisgarh state of India is the first state in the country to have enunciated Peoples oriented state forest policy which provides new direction to forest management. There are also some backgrounds which have been created situations for the establishment of PPA.

People's Protected Area (PPA) envisions a proactive and people's friendly framework so that it becomes Poor People's Pool of Assets (PPA) for meaningful poverty alleviation and their enhanced well being. Like declaration of Chhattisgarh as 'Herbal state' which, non destructive harvesting, processing and marketing of herbal medicine in the forest of the state. To translate the concept of PPA on the ground and to make the conservation efforts people friendly work has been initiated at 8000 ha. of reserved forest of 8 forest division in the state [5].

Thus the project is just another step after implementation of joint forest management programme and basic theme of the project is to prepare a peoples friendly framework for sustain development, livelihood security and biodiversity conservation through non wood forest products.

While the traditional forest management is focused mainly on the timber spices and all the techniques and tool and research inputs were concentrated on the timber now all the efforts is for the NWFP. People living near these forest areas have very sound knowledge about different kinds of NWFP and occurrence and utilization of these forest species.
Most of the times due to their poor economic base and low bargaining power, villagers are compelled to follow barter system and very cheap items in return to the high cost NTFPs [6].

Joint Forest Management can effectively monitor the NTFP activities at local level aimed at providing better income opportunities to local people and strengthen the institution itself [7].

Study Site: Forest of Raigarh division, are classic example of rich luxuriant tropical Sal- forest [8]. The tropical forest are now gaining an identity as center for Biodiversity for future, a well - managed and properly used tropical- forest constitute massive potential source of energy, a powerful tool to fight hunger and a strong basis for generating economic wealth.

The present study been conducted on three villages of Tamnar block of Raigarh Forest division. These villages are surrounded by 3160 hectare of dense forest (Table I).

TABLE I: DETAILS OF THE STUDY AREA

\begin{tabular}{|cc|}
\hline Division: Raigarh, & Range: Tamnar \\
\hline Committees & Name of Village \\
\hline Village forest Committee & Urba \\
Village Forest Committee & Pelma \\
Village Forest Committee & Hinzer \\
\hline Total Reserve Forest Area: & 3160 ha. \\
\hline
\end{tabular}

\section{Methodology}

Techniques were based on PRA, RRA as well as questionnaire methods depending upon the suitability. Secondary data have been collected from forest division office of Riagarh Forest Division and range office of Tamnar.

\section{OBSERVATION}

Out of total 470 families of these villages chief occupation of 250 families is agriculture and 200 families are earning their livelihood by working as agricultural labor. But all the families are earning return by collection of Tendu patta (leaves of Diospyrus melexylon), Chiroinji, Mahua(flower and seeds of Madhuka indiaca), Sal seed( seed of Shorea robusta) etc.

Economic condition of villagers is very poor and $80 \%$ families of these areas are living below poverty line. Their poverty has been increasing their dependence over forest. The most important fact come to know during the survey was that every village house knows about the importance of forest conservation.

Before participatory management programme has been on work till 1996 as villagers have not been knowing about the importance of forest for soil and water conservation land fertility had been eroding day by day, dependency of villagers over forest was very high as about 6 to 8 months villager gets their fuel, fodder and income from forest by selling fuel wood and other minor forest produces. In the village absence of irrigation facility, due to absence of proper 
road facilities and lack of education and other social obstruction creates haphazard of poverty.

During PRA it had come to know that in reserve forest of Urba, Pelma and Hinzar about 24 diverse species of medicinal importance have been identified with the help of local knowledge as the villagers have been using all these plants for treatment of many different diseases (Table II).

TABLE II: List of THE AVAILABLE MEDicinal Plants

\begin{tabular}{|c|c|c|}
\hline Sr. No. & Botanical Name & Parts Used \\
\hline 1 & Acacia nilotice Delite & Pods, leaves, bark, \\
\hline 2 & Aegle marmelos L. Corr. & Roots, leaves, fruit \\
\hline 3 & Azaflirachta indica & Bark leaves, flowers, \\
seed, oil
\end{tabular}

Goods and services from the PPAs, more importantly non-wood forest products originating from diverse sources ranging from large plants to micro flora consisting of heterogenous products, constitute a critical lifeline for poor forest dwellers by providing family sustenance and livelihood. Due to their recurrent availability on annual/seasonal basis and immense socio-cultural, economic, environmental and industrial development potentials, NWFP hold a promise for developing interesting mechanism for sustainable livelihood approaches.

As the National Forest Policy, 1988 and directives as well as decisions of the Supreme Court of India will provide the basic policy framework of PPA.

1) Harvesting of minor forest produce will be on non-destructive basis.

2) The members of the Gram Sabhas will be free to collect minor forest produce for their own consumption.

3) The manner, frequency and intensity of minor forest produce collection for any use other than bona-fide domestic use by the members of the Gram Sabhas will be in accordance with the prescription of a management plan prepared by Zila Panchayat in conformity with the guidelines as may be notified from time to time.

Thus non destructive harvesting of non wood forest produce became significant. Besides ameliorating the soil and water conservation regime, which adds substantially to the enhanced agricultural food production, forest products reinforce the food security in many ways. In the rural context cattle are important component of the socio-economic set up. In the complex chain of food web, cattle are secondary food producers too. They derive their food from the forests, which they convert into animal proteins in form of milk, fat, meat and other dairy products to be used by human beings [9]. Although excessive grazing pressure, more importantly the one beyond the carrying capacity, has been viewed as a constraint by foresters, PPA endeavors to accommodate multiple use of natural resource on sustainable basis so that food resources are available to the people as well as cattle.

\section{CONCLUSION}

We have concluded from our studies that

1) Although people are knowing about the utilization of forest resources and they are using different types of forest produces in their day to day to life but except Tendu patta collection they are not seriously taking any other resource for their economic betterment.

Keeping in view that for the poor communities' economics precedes ecology and conservation and in tune with their priority there has to be sharp focus on productivity enhancement so that they can reap better economic returns.

2) For the purpose for those who possess land, a programme must be initiated to upgrade the productivity of the agriculture system by land shaping, constructing stop-dams, tube wells and making available to them other inputs for better crop husbandry practices, so that the land under rain fed condition is transformed into double cropped or in certain cases even triple cropped land.

3) Enhancing the productivity of the land provides good harvest as well as gainful employment round the year. All these on-farm activities can be adopted as a package for improving the socio-economic conditions of the people who otherwise practice subsistence agriculture.

4) For landless persons off-farm activities leading to income generation can be devised by using forest biomass and other resources. In the first category, activities like NWFP collection, rope making, honey collection, nursery raising etc can be considered, whereas in the latter category schemes like poultry, piggery, mushroom cultivation, shop-keeping, grocery etc. can be envisaged.

5) It is noticed that the villagers are not able to get true value of the forest produce collected by them because of inadequate marketing facilities available to them. In fact marketing is the weakest link in the development of NWFP sector.

It is concluded that all the conservation and propagation efforts in the field of NWFP would be of no use if proper market linkages were not well established. 
Thus proper development of marketing infrastructure is must.

6) It is concluded that all the conservation and propagation efforts in the field of NWFP would be of no use if proper market linkages were not well established.

Thus proper development of marketing infrastructure is must. Thus all these activities will be helpful for amelioration of the economic conditions of forest.

On the other hand it will reduce villagers dependency over forest which will be beneficial for protection of biodiversity of forest. Cultivations of medicinal species will also helpful from conservation point view.

On the first step all these programmes needs intense awareness generation programme and it should be object of all the research work that they convert their studies into easier terms and communicate it to rural masses which could be only way of fulfilling object of resource management in true sense.

7) The initial entry point activity would be to create awareness among the local people about their latent strength, availability of natural resources and potential of using them on sustainable basis by technological up gradation. Broadly, this may be achieved by developing the hardware of the system comprising of physical activities eg. water harvesting structures, drinking water facilities, common facility centers, village level processing units, storage units etc. On the other hand, interventions like raising awareness, bridging credibility gap, confidence building, soliciting meaningful participation of the local communities and empowering them, creating income generation opportunities through skill development etc would constitute the software of the system.

\section{REFERENCES}

[1] K. P. Shukla, "Forest working plan of Raigarh divison 1955-56," Forest Dept. Publication, pp. 15-20, 1955.

[2] D. R. Thapliyal, "Forest working plan of Raigarh divison 1985-86," Forest Dept. Publication, pp. 5-12, 1985.

[3] Astogi and Alind, "Training intervention - A need for joint forest management," Indian Forester, vol. 120, no. 7, pp. 621-629, July 2000.

[4] K. K. Kaushal and J. C. Kala, "Applying the sustainable livelihood approach to joint forest management projects in India," International Forestry Review, vol. 6, no. 1, pp. 13-18, 2004.

[5] Forest Department. [Online]. Available: http://www.cgforest.nic.in

[6] C. Chhadrasekhran, "Role of non wood forest products in sustainable forest management," Forest Usufructs, pp. 23-49, 1998.

[7] A. N. Purohit, "Medicinal plants-need for upgrading technology for trading in traditionspp," Harvesting Herbs, pp. 49-75, 1997.

[8] S. B. Guru, Gazetteer of Raigarh District, Madhya Pradesh: Govt. Publication, 1978, pp. 23-24.

[9] S. K. Gupta, Joint Forest Management: Aspects and Prospects, APH Publishing Corporation, New Delhi, 2000, pp. 173-180.

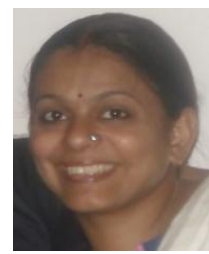

Garima Tiwari received the B.Sc. and M.Sc. degrees in forestry from Guru Ghasidas University, Bilaspur, Chhattisgarh, India. During 2001-2004, she did research work on changing patterns of forest management in Central India. She is now working as an assistant professor in forestry at Guru Ghasidas University, Bilaspur, Chhattisgarh, India. 